\title{
Double-surgical-mask-with-slit and COVID-19 prevention
}

We would like to discuss the letter from Lazaridis et al., "Double-surgical-maskwith-slit" method: reducing exposure to aerosol generation at upper gastrointestinal endoscopy during the COVID-19 pandemic" [1]. The authors noted that "Despite its snug fit, the narrow slit still allows easy passage of the endoscope and any required suction of the oral cavity, while the double mask itself (and its curtain-like slit) minimizes any 'leakage' of generated aerosols" [1]. The main question here is whether or not doubling or even tripling of masks can help to increase protection from aerosols containing pathogens. The material used for mask production is an important determinant regarding protection. In general, the size of the virus is extremely small and it might pass through the pores of a face mask [2]. This is an important physical limitation of mask use with regard to protection from COVID-19 [2]. The number of layers of face masks can contribute nothing to protection if the pore size of the mask at all the layers is still lar- ger than the pathogen. The use of negative pressure rooms for patient care might be a more effective measure for controlling the spread of disease.

Competing interests

The authors declare that they have no conflict of interest.

The authors

Sora Yasri ${ }^{1}$, Viroj Wiwanitkit ${ }^{2}$

1 Private academic practice, Bangkok Thailand

2 Dr DY Patil University, Pune, India

\section{Corresponding author}

Sora Yasri, PhD

Private academic practice, Bangkok 101044, Thailand

Fax: +66-3-4839493

sorayasri@outlook.co.th

\section{References}

[1] Lazaridis N, Skamnelos A, Murino A et al. "Double-surgical-mask-with-slit" method: reducing exposure to aerosol generation at upper gastrointestinal endoscopy during the COVID-19 pandemic. Endoscopy 2020; 52: 928-929

[2] Sriwijitalai W, Wiwanitkit V. N-95 face mask for prevention of Wuhan novel coronavirus: It is actually effective? Int J Prev Med 2020; 11: 81

Bibliography

\section{Endoscopy 2021; 53: 96-96}

DOI 10.1055/a-1293-8107

ISSN 0013-726X

published online 9.11.2020

(c) 2020. Thieme. All rights reserved. Georg Thieme Verlag KG Rüdigerstraße 14, 70469 Stuttgart, Germany 